\title{
The Use of the VEC Model to Study the Impact of the Third Party Payment on the Interest Market in China
}

\author{
Yaqian $\mathrm{Pan}^{1}$, Shubing $\mathrm{Li}^{1}$, Xinxin Chen ${ }^{1}$, Shiqi $\mathrm{Yu}^{1} \&$ Lijuan $\mathrm{Yu}^{1}$ \\ ${ }^{1}$ Finance Department of International Bussiness School, Jinan University, Zhuhai, China \\ Correspondence: Yaqian Pan, Finance Department of International Bussiness School, Jinan University, Qianshan \\ Road 206\#, Zhuhai City, Post No 519070, Guangdong Province, China. Tel: 86-158-2058-0592. E-mail: \\ 1710170590@qq.com
}

Received: November 24, 2016

Accepted: December 14, 2016 Online Published: January 10, 2017

doi:10.5539/ijef.v9n2p100

URL: http://dx.doi.org/10.5539/ijef.v9n2p100

\begin{abstract}
This paper aims to study the effects of cross section of Internet finance and mobile payment on the Internet financial deepening and the interest rate liberalization. Because more than $50 \%$ of online payment is completed by way of mobile payments and financial products in Internet finance also have such two ways as online transactions and mobile client transactions, the interest rate index on behalf of the Internet finance can be largely replaced by the return of financial products in it. The study of the relationship between return of common monetary fund in transactional Internet finance and quasi benchmark fund-SHIBOR helps to determine the effect of Internet mobile payment on Internet financial deepening and the interest rate liberalization. First, ensure the stability of time series data on SHIBOR, Yu'E Bao returns, payment of the third party with ADF test and Johansen co-integration test and then build the VEC model and perform T test and AR stationary test, then make response analysis on impulse function to describe the impact of endogenous variables. Finally, make analysis and risk prevention suggestions according to empirical results based on the market situation.
\end{abstract}

Keywords: mobile payment, internet finance, VEC model, SHIBOR, impulse response function

\section{Background of Problems}

At 5:00 a.m. on February 18, 2016, Apple Pay came officially online in China. Third-party payment industry is growing. Apple Pay's accession will make competition in this market more intense. The turbulent market will once again face the surging situation. In recent years, the rapid development of Internet technology and the growing sophistication of China's financial markets have promoted exchange and integration between domestic Internet and finance. Internet finance, developing based on the third-party payment technology, emerges at the right moment.

Internet finance and interest rate of money market have a close relationship and interest rate pricing of the former is based on the latter. For example, the funds raised by the most representative financial product in Internet finance balance, Yu'E Bao, are mainly invested in the main investment in contracted deposits in bank, returns of which are closely related to the interest rate of money market; interest rates or yield of cyber debit and credit, public financing and other financial products should also fully consider a variety of risk premiums on the basis of Market benchmark interest rate. Internet financial funds focus on the interest rate of money market so that individuals or enterprises purchasing Internet financial products directly benefit from the marketization of interest rates.

The development of third-party payment has a significant impact on that of Internet finance and the development of Internet finance will bring a greater impact on market interest rate:

First, the mode of payment of Internet finance is based on the third-party payment. In the future, with application field of the third-party payment continuing to expand, the scale of Internet finance industry will greatly expand.

Second, the payment mode of Internet finance is also based on third party payment, which can really realize payment with any method anytime, anywhere. With the rapid development of the technology of identity authentication and security software, the third party payment not only solve the problem of micro payment, but also can solve large payment, which replaces the function of cash and check, also can derive an alternative to credit card function. The derivative business is produced with the development of the Internet. In the future, with 
the advance of technology and the increasing expansion of domain and range of the third party payment, many Internet Financial extension and application can make more development and expansion on this basis.

\section{Developmental Status}

The interest rate policy of China's financial industry is changing from the original financial suppression to the gradual financial deepening. As a result, market interest rates become more important and they will ultimately have an impact on the overall interest rate system. Marketable interest rate is a double-edged sword. Commercial banks and other traditional financial institutions as the main target of market-oriented interest rate reform will inevitably be greatly affected. Product marketing interest rate promotes the traditional bank to market oriented and promotes the development of the financial system, but also brings for the traditional finance challenges and impacts. At present, a variety of rising Internet financial products relying on third-party payment are emerging, which brings new risks and opportunities for the traditional financial industry.

Mobile payment is considered to be a huge market for rapid development worldwide. In China, the mobile payment is in the explosive growth period and all kinds of mobile payment means emerge in endlessly. The mobile payment in 2014 was selected into annual top ten hot spots of e-commerce and 2015 is considered the first year of mobile payment. EnfoDesk in January 2015 released 2014 core data inventory report of China's Internet industry. Report data showed that in 2014 the mobile payment continued to push up; "Shou Tao" was in rapid growth; transaction size of mobile third party payment has reached 7,000 billion yuan; ring growth of mobile payment was 5 times larger. In 2014, enterprise Internet acquiring service in China's third-party payment was close to 9,000 billion yuan, with ring growth approximately up to $48 \%$. Transaction size of third-party mobile payment reached 7,766 billion yuan and once again ushered in nearly 500\% ring growth and would continue to maintain the ultra-high-speed development following the explosive growth in 2013 (ring growth of $800 \%$ ). It can be seen that with cooperation from the industrial chain and continued investment of manufacturers, user habits have been formed.

Personal Internet devices of Internet users show a significant trend to mobile phone client and the proportion of mobile Internet continues to increase while the proportion of surfing the Internet on traditional desktop computers, laptops, tablet PCs, is showing a downward trend. As of the end of 2015, the proportion of China's Internet users with the use of mobile phones is as high as $90.1 \%$.

With significant trend of mobile terminal replacing PC, mobile payment has become an important direction and future trend of Internet payment development. E-commerce is shifting from B2B model and B2C model to O2O model, which further promotes Alipay, TenPay and other mobile payment giants to snatch ad occupy mobile payment market. As is predicted by relevant agencies, in 2015, transaction size of China's mobile payment will exceed 7,000 billion yuan, as well as that of third-party Internet payment close to 14 trillion yuan and the size of registered account through Internet payment will usher in a new breakthrough. From these signs, it is not difficult to see that driven by government monitoring departments, the era of rapid development of mobile payment has come.

\section{Literature Overview}

In his book, Money and Capital in Economic Development, Ronald McKinnon successfully analyzed the harm of financial repression. Next, he offered the policy order of financial liberalization in The Order of Economic Liberalization: Financial Control in the Transition to a Market Economy, which exerted profound influence on the transformation of developing countries, especially the countries with centrally-planned economy, including China.

The marketization of interest rates is an important force for the economic development of a country, which is closely related to the financial deepening effect. The definition of the marketization of interest rates in foreign countries is mainly based on Ronald McKinnon and Shaw's theory of financial repression and financial deepening, in which the control of the interest rate causes financial repressions, resulting in that the interest rate is far below the market's average and this makes it impossible to effectively allocate capital.

However, one dimension of the Internet financial deepening is the marketization of interest rates. It is necessary to loosen the price control of the interest rate and make it marketable to faithfully reflect the supply and demand of capital. By improving the real interest rate and decreasing the difference, it absorbs investors, which promotes the economic development of one country.

In Can Yu Ebao Influence the Inter - bank Market Interest Rate? - An Empirical Analysis Based on Shibor Data, Zhang Yu and Zhang Jiannan expounded on the relations between the third-party payment represented by Yu Ebao and the marketization of interest rates. Yu Ebao is the first Internet Monetary Fund product jointly launched 
by Ali Finance and Tianhong Asset. It is one balance value-added service constructed by the third-party payment platform-Alipay.

Regarding the relations between the network fund and its interest rate, as well as benefits, Yu Ebao avoids the monitoring and regulation risks through the institutional arrangements, controls market risks through client selection, and lowers the mobility risk through Big Data, so as to improve benefits.

He Qiang, in his Pay attention to preventing financial risks to promote the healthy development of Internet finance, pointed out that legal interest rate and market interest rate coexisted currently and between the two types of interest rates there had been interest margins; ordinary investors could only have deposits and loans in the bank in accordance with the legal interest rates and could not directly invest in the money market; Yu'E Bao, as a channel, got through barriers between the market interest rate and the legal deposit interest rate so as to provide investors with the opportunity to enjoy market interest rates to achieve high returns. In this model of source of profit, the emergence of Yu'E Bao, etc., in fact, exacerbated deposit substitution, increased funds and information supply in the money market, which would inevitably affect money market interest rates.

Gao Shanwen, in his Interest rate liberalization and rise of Yu'E Bao, believed that interest margins between financial management, monetary funds and savings reflected purchase cost of different products; Yu'E Bao declined purchase costs through channel change and weakened market segmentation and made petty cash flow into the money fund which in the long term would help to reduce market prices and have a significant impact on Interest rate liberalization.

\section{An Empirical Analysis of the Interest Rate Liberalization Based on VEC Model}

The interest rate liberalization is closely linked with the financial deepening effect. The definition of interest rate liberalization abroad is mainly based on the theory of "financial repression" and "financial deepening" of McKinnon and Shaw. That is, interest rate regulation leads to financial repression so that the interest rate is far below the average level of the market, resulting in a failure of efficient configuration of capital. One of the dimensions of Internet financial deepening is Interest rate liberalization, which relaxes the price control of interest rates and makes them marketable, thus truly reflecting the relationship between capital supply and demand. By raising actual interest rate, narrowing interest margin, attract investors to invest so as to promote a country's economic development.

\subsection{Theoretical Basis and Hypothesis}

An important part of the Internet finance is network fund, which attracts a large number of investors for its convenient operation, relatively high income and low purchase threshold. In June 2013, Yu'E Bao, China's first Internet money fund product, was launched by AliFinance and Tianhong Fund, followed by the similar huoqibao, WeChat financial management and other Internet financial funds.

Table 1. Top ten of online funds in scale

\begin{tabular}{|c|c|c|c|c|c|c|}
\hline Product & Docking Fund & $\begin{array}{c}\text { Benefit } \\
\text { per } 10,000\end{array}$ & $\begin{array}{l}\text { On the } 7 \text { th of } \\
\text { the year yield }\end{array}$ & $\begin{array}{l}\text { Purchasing } \\
\text { threshold (yuan) }\end{array}$ & $\begin{array}{c}\text { Scale (100 } \\
\text { million yuan) }\end{array}$ & $\begin{array}{c}\text { Market } \\
\text { share }\end{array}$ \\
\hline Yu Ebao & Tianhong Yu Ebao & 0.6427 & 2.364 & 1 & 8163.12 & $56.78 \%$ \\
\hline $\begin{array}{l}\text { Howbuy } \\
\text { Cunchuguan }\end{array}$ & ICBC Credit Suisse MMF & 0.6496 & 2.426 & 1 & 1529.06 & $10.64 \%$ \\
\hline Cash Fastline & ICBC Credit Suisse MMF & 0.6411 & 2.407 & 0.01 & 1529.06 & $10.64 \%$ \\
\hline Zhanggui Wallet & Xingquan Tianlibao & 0.6922 & 2.771 & 0.01 & 690.33 & $4.80 \%$ \\
\hline Baidu Baizuan & Huaixa cash profit-gain currency A & 0.6335 & 2.295 & 1 & 641 & $4.46 \%$ \\
\hline $\begin{array}{l}\text { Huaxia } \\
\text { All-in-One }\end{array}$ & AHuaxia cash profit-gain currency A & 0.6335 & 2.295 & 0.01 & 641 & $4.46 \%$ \\
\hline $\begin{array}{l}\text { Telecom } \\
\text { Tianyibao }\end{array}$ & Huitianfu Xianjinbao Currency & 0.6693 & 2.595 & 0.01 & 394.09 & $2.74 \%$ \\
\hline $\begin{array}{l}\text { NetEase Xianjin } \\
\text { Bao }\end{array}$ & Huitianfu Xianjinbao Currency & 0.6693 & 2.595 & 0.01 & 394.09 & $2.74 \%$ \\
\hline Weicaifu Deposit & Huitianfu Xianjinbao Currency & 0.6693 & 2.595 & 0.02 & 394.09 & $2.74 \%$ \\
\hline
\end{tabular}

Source: Sina Finance.

Legal interest rate and market interest rate coexisted currently and between the two types of interest rates there had been interest margins; ordinary investors could not directly invest in the money market; the emergence of Yu'E Bao and other similar finance products, got through barriers between the market interest rate and the legal 
deposit interest rate so as to provide investors with high returns (He Qiang, 2014). From the profit model of Yu'E Bao, the emergence of Yu'E Bao exacerbates deposit substitution and increases capital flow in the money market which will inevitably have a certain impact on the market interest rate. And inter-bank marketable interest rate -SHIBOR plays important roles of benchmark interest rate and market attribute source in China's comprehensive process of marketization of interest rates. To further perfect and improve marketability and volatility of SHIBOR has become an important task to promote marketization of interest rates.

Among them, the growth of online payment by mobile phones is particularly rapid, with the user base reaching 358 million and the growth rate of $64.5 \%$. The proportion of netizens' online payment increases from $39 \%$ to $57.7 \%$ as shown in Figure 6-4. So you can determine, nearly 50\% of online payment is by mobile phones. The proportion of investment through the financial APP mobile payment increases year by year. Therefore, returns of Yu'E Bao, to a large extent, can be used as a measurement index for mobile payment vs. the Internet financial interest rate liberalization.

Based on the above analysis, this chapter assumes:

1). Yield changes of Yu'E Bao and other Internet financial products will have a certain impact on returns and volatility of the capital market, to a certain extent, to promote the process of interest rate marketization.

2). Risk changes of Yu'E Bao and other Internet financial products will impact on the entire capital market, which is transmitted to the entire financial system by multi-channel, affecting the liquidity of funds.

\subsection{Data Source and Pre-Processing}

For the data in this chapter, returns of Yu'E Bao is derived from WIND Information (http://www.wind.com.cn/); SHIBOR rates are from the Shanghai Interbank Offered Rate Network (http://www.shibor.org/); volume of trade for third-party payment is from iResearch (http://www.iresearch.com.cn/) and in part from the China Internet Information Platform (http://www.cnidp.cn/).

In the data preprocessing section, first select the same time interval from August 2013 to April 2016 for returns of Yu'E Bao, SHIBOR data and volume of trade for third-party mobile payment. Due to the partial missing value of the third party's mobile payment data, use SPSS to make missing value analysis on third-party mobile payment data and replace individual missing value with linear interpolation. After processing the missing and obvious false data, the data of the three indicators are inconsistent in dimension. In order to make the dimensions of variables consistent, in this paper, we standardize the data. Commonly used standardized treatment methods are maximum difference normalization method, standard deviation normalization and index normalization method. According to the characteristics of the data obtained in this paper, Z-score normalization is chosen to convert the variables into standard variables subject to normal distribution.

\subsection{ADF Test and Co-Integration Test}

ADF test is mainly used for the stationary test for time series. In the process of econometric analysis, the ADF test is mainly used in the form of logarithm, because the logarithmic form can eliminate the possible heteroscedasticity and obtain the stationary time series. At the same time, if for the original data, ADF test fails, it will be re-tested in the form of first-order differential. The results are shown in Table 2.

Table 2. ADF testing results

\begin{tabular}{ccccc}
\hline Variable & ADF value & Critical value of 5\% & P value & Testing results \\
\hline YEBER & -0.479338 & -2.95711 & 0.0287 & Unstable \\
DYEBER & -8.301839 & -2.960411 & 0 & Stable \\
SHIBOR & -2.707939 & -2.95711 & 0.0837 & Unstable \\
DSHIBOR & -8.301839 & -2.960411 & 0 & Stable \\
TRDTS & 1.916714 & -2.95711 & 0.9997 & Unstable \\
DTRDTS & -4.65701 & -2.960411 & 0.0008 & Stable \\
\hline
\end{tabular}

As shown in Table2, the time series of the three indexes are not stationary. The critical value of the ADF value is less than 5\%. The $\mathrm{P}$ value is more than 0.05 . However, the time series re-tested with first-order differential becomes stationary and the $\mathrm{P}$ value is close to 0 , which indicates that with significance of $5 \%$, the time series is stationary. It can be more clearly seen from the trend graph of original variables and that by first-order differential, as shown in Figure 1,2,3. Therefore, the establishment of VAR model uses the time series re-tested with first-order. 
SHIBOR

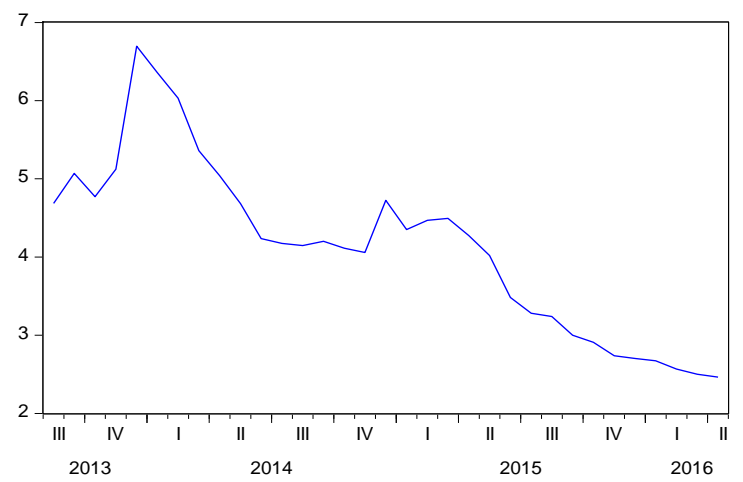

Figure 1. Tendency chart of SHIBOR's time sequences

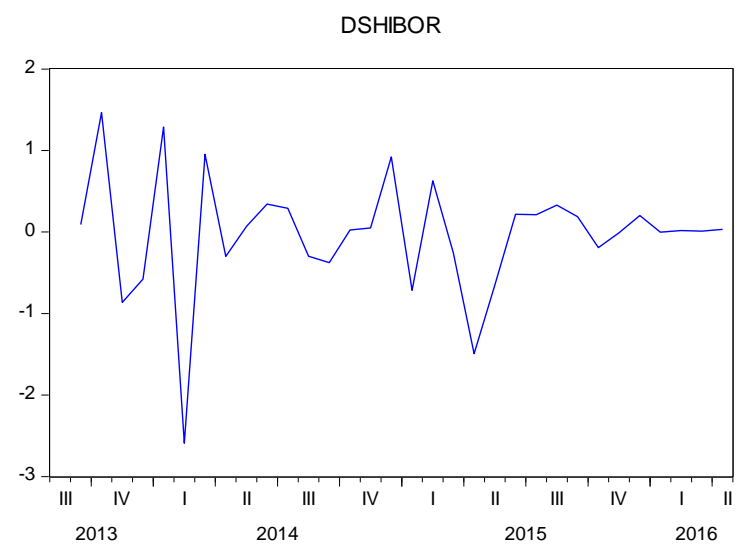

Figure 2. Tendency chart of SHIBOR after the first-order difference

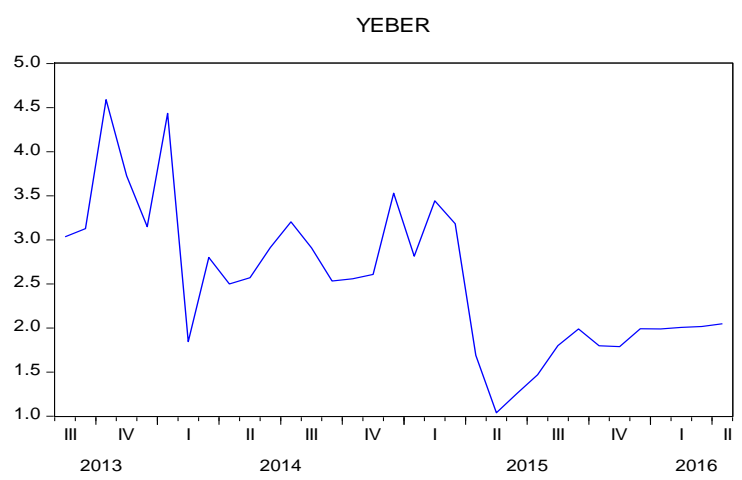

Figure 3. Tendency chart of YEBER's time sequences

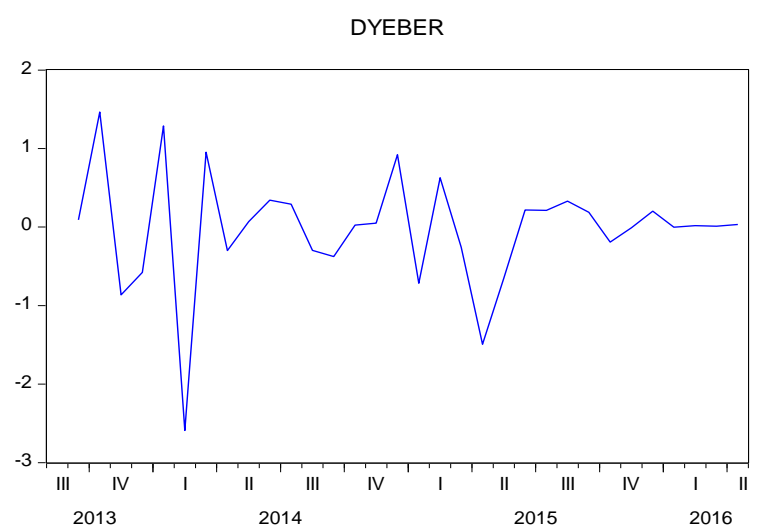

Figure 4. Tendency chart of YEBER after the first-order difference 


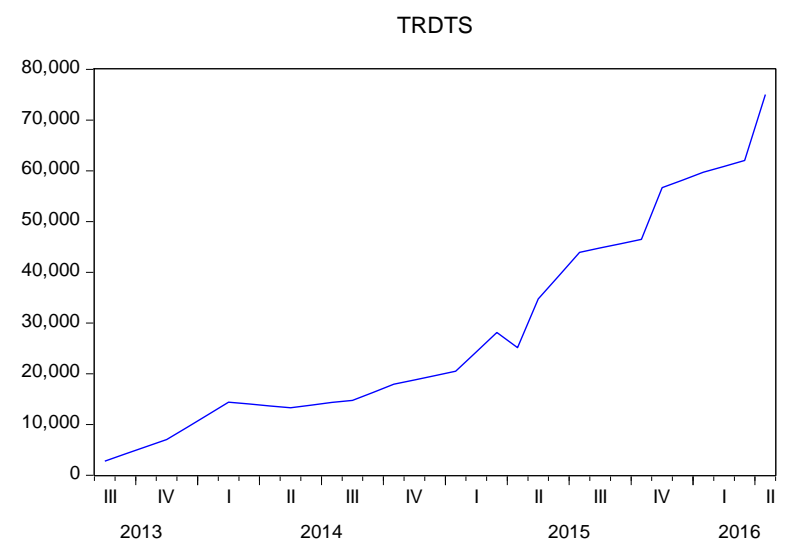

Figure 5. Tendency chart of TRDTS's time sequences

DTRDTS

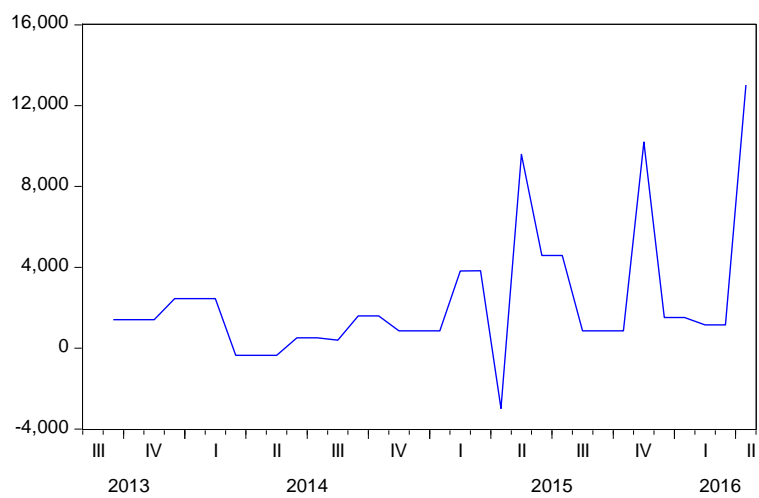

Figure 6. Tendency chart of TRDTS after the first-order difference

Since the time series is stationary as required when the VEC model is established and most of the time series are non-stationary in practice, the non-stationary trend in the series is usually eliminated by the difference method, which makes the series stationary. The purpose of co-integration test is to determine whether a set of non-stationary series is co-integrated. Consider the VAR model with order $p$ :

$$
y_{t}=A_{1} y_{t-1}+\cdots+A_{p} y_{t-p}+B x_{t}+\varepsilon_{t}
$$

Where $y_{t}$ is an $k$-dimensional vector containing non-stationary $I(1)$ variables; $x_{t}$ is a definite d-dimensional vector and $\varepsilon_{t}$ is a perturbation vector. We can rewrite the VAR in the following form:

$$
\begin{gathered}
\Delta y_{t}=\Pi y_{t-1}+\sum_{i=1}^{p-1} \Gamma_{i} \Delta y_{t-i}+B x_{t}+\varepsilon_{t} \\
\Pi=\sum_{i=1}^{p} A_{i}-I \quad \Gamma_{i}=-\sum_{j=i+1}^{p} A_{j}
\end{gathered}
$$

In this paper, we use the Johansen co-integration test: the series y has linear trend; co-integration equation only with intercept:

$$
H_{1}(r): \Pi y_{t-1}+B x_{t}=\alpha\left(\beta^{\prime} y_{t-1}+\rho_{0}\right)+\alpha_{\perp} \gamma_{0}
$$

The determining tendency is tested, and its testing results are shown in Table 3.

Table 3. Johansen co-integration testing results

\begin{tabular}{ccccc}
\hline Hypothesized & & Trace & 0.05 & \\
\hline No. of CE(s) & Eigenvalue & Statistic & Critical Value & Prob.** \\
None $*$ & 0.669945 & 46.34430 & 29.79707 & 0.0003 \\
At most 1 & 0.296204 & 14.19792 & 15.49471 & 0.0777 \\
At most $2 *$ & 0.129177 & 4.011176 & 3.841466 & 0.0452 \\
\hline
\end{tabular}

Trace test indicates 1 cointegrating eqn(s) at the 0.05 level.

* denotes rejection of the hypothesis at the 0.05 level. **MacKinnon-Haug-Michelis (1999) p-values.

Unrestricted Cointegration Rank Test (Maximum Eigenvalue). 


\begin{tabular}{cccc}
\hline Hypothesized & & Max-Eigen & 0.05 \\
\hline No. of CE(s) & Eigenvalue & Statistic & Critical Value \\
None $*$ & 0.669945 & 32.14638 & 21.13162 \\
At most 1 & 0.296204 & 10.18674 & 14.26460 \\
At most 2* & 0.129177 & 4.011176 & 3.841466 \\
\hline
\end{tabular}

Max-eigenvalue test indicates 1 cointegrating eqn(s) at the 0.05 level.

$*$ denotes rejection of the hypothesis at the 0.05 level.

**MacKinnon-Haug-Michelis (1999) p-values.

According to the results in Table 3, the first column shows the number of co-integration relationship under the establishment condition of the null hypothesis. The second column is the eigenvalue of the matrix according to the descending order. The third column is the trace test statistic or the maximum eigenvalue statistic; the last two columns are the critical values at the $5 \%$ and $1 \%$ levels, respectively. In the trace test and the maximum eigenvalue test, the first line shows that the null hypothesis is rejected at the level of 5\%. That is, the assumption that there is no co-integration relationship is rejected. That is, the covariant equation exists for the three variables. The second line shows that the null hypothesis is accepted at the level of 5\%. Namely, at most one co-integration relationship is accepted. That is, there is at most one co-integration equation for the three variables. The third line shows that the null hypothesis is rejected at the level of 5\%. Namely, at most two co-integrating relationships are rejected. That is, there are at least two co-integration equations for the three variables. It can be concluded that there exists a long-term equilibrium relationship among the variables and then the VEC model is established for analysis.

\subsection{Construction of the VEC Model}

Engle and Granger (1987) pointed out that the linear combination of two or more non-stationary time series may be stationary. If such a stationary linear combination exists, these non-stationary (with unit root) time series are considered to be co-integrated with each other. This stationary linear combination is called the co-integration equation and can be interpreted as a long-run equilibrium relationship between variables.

The vector error correction model (VEC) is a constrained VAR model and has co-integration constraints in the explanatory variables, so it is mostly used for modeling of non-stationary series with co-integration relations. When there is a large range of short-term dynamic fluctuations, VEC's expression will limit the long-term behavior of their endogenous variables to converge to their co-integration relationship. Since a series of partial short-term adjustments can correct long-run equilibrium deviations, the co-integration term is termed the error correction term.

\subsection{Setting of the VEC Model}

The lag specification: "1 1" will include the lag of the first-order differential terms on the right-hand side of VEC model. i.e. VEC model is the lag of the two-order differential terms of the original variable. In order to estimate the VEC model without first-order differential terms, the form of delay is specified as " 00 ".

According to the Johansen co-integration test, the number of co-integration relationship is set to two and the VEC model is designated as a linear model with an intercept term and no trend term. Therefore, the third one is selected from the five trend assumptions.

\subsection{Construction of the VEC Model and Stability Test}

Set up the the VEC model's coefficients and the T testing statistics, as is shown in Table 4.

Table 4. VEC model's coefficients and T statistics

\begin{tabular}{cccc}
\hline Cointegrating Eq: & CointEq1 & CointEq2 & \\
\hline DSHIBOR(-1) & 1.000000 & 0.000000 & \\
DTRDTS(-1) & 0.000000 & 1.000000 & \\
DYEBER(-1) & -0.488214 & 7545.969 & \\
& $(0.23349)$ & $(1991.73)$ & \\
C & {$[-2.09093]$} & {$[3.78866]$} & \\
Error Correction: & -0.001621 & -1378.568 & \\
CointEq1 & D(DSHIBOR) & D(DTRDTS) & 0.093200 \\
& -1.358638 & -1229.794 & $(0.10536)$ \\
& $(0.16694)$ & $(913.482)$ & {$[0.88459]$} \\
\hline
\end{tabular}




\begin{tabular}{cccc}
\hline CointEq2 & $-1.44 \mathrm{E}-05$ & -0.516161 & $-6.99 \mathrm{E}-05$ \\
& $(3.3 \mathrm{E}-05)$ & $(0.18292)$ & $(2.1 \mathrm{E}-05)$ \\
& {$[-0.43065]$} & {$[-2.82186]$} & {$[-3.31484]$} \\
$\mathrm{C}$ & -0.001935 & 374.6355 & -0.013581 \\
& $(0.12908)$ & $(706.314)$ & $(0.08147)$ \\
& {$[-0.01499]$} & {$[0.53041]$} & {$[-0.16670]$} \\
\hline
\end{tabular}

From Table 4, we can see that the first part is the estimated value of parameters of the co-integration equation and the variable name is written in the form of the first-lag. The second part is the estimated value of parameters of the VEC model, where the value corresponding to CointEq1 represents the co-integration equation, that is, the estimated values of coefficients of error correction terms and the corresponding standard deviation and $\mathrm{T}$ test statistics are given below the estimated values of parameters. Generally, the overall effect of the VEC model is more concerned. The overall test results of the VEC model are shown in Table 5.

Table 5. Testing results of the VEC model

\begin{tabular}{|c|c|c|c|}
\hline R-squared & 0.711045 & 0.230990 & 0.334652 \\
\hline Adj. R-squared & 0.690405 & 0.176060 & 0.287127 \\
\hline Determinant resid covariance (dof adj.) & & 1544544. & \\
\hline Determinant resid covariance & & 1138123. & \\
\hline Log likelihood & & -348.1071 & \\
\hline Akaike information criterion & & 23.42626 & \\
\hline
\end{tabular}

As shown in Table 5, the $\mathrm{R}^{2}$ value is 0.71 , which indicates that the fitting degree of the model is good. AIC and SC of the model are 23.42 and 24.12, respectively, tending to be smaller. To further ensure that the model is stationary, AR stationary test is performed for the model. The test results are shown in Figure 6.

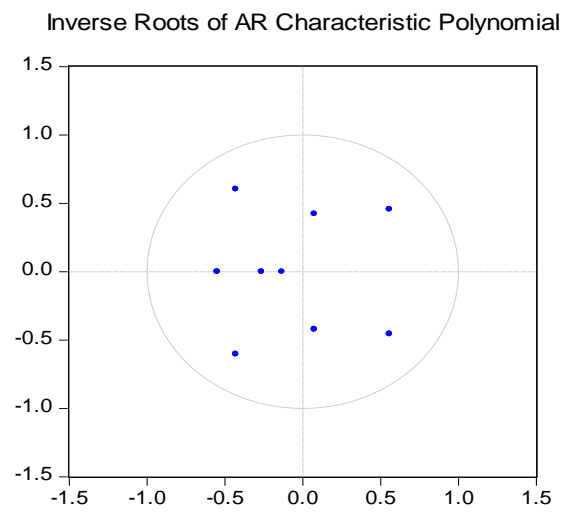

Figure 7. AR test

Seen from Figure 7, the inverse values of VEC's all roots are smaller than 1 and distributed within the unit circle, meaning this model has a stability and can carry out the impulse function response analysis.

\subsection{Impulse Response Function}

The impulse response function is used to measure the impact of a standard deviation impulse from a random disturbance term on the present and future values of the endogenous variables. The impulse response function tries to describe the trajectory of these impacts and shows the process of how the perturbation of any variable affects all other variables and the final feedback to themselves. In this paper, the Monte Carlo method is used to calculate the standard error of the response function. The impact effect of the endogenous variables DYEBER and DTRDTS on the variable DSHIBOR is shown in Figure 8. 
Response of DSHIBOR to DYEBER

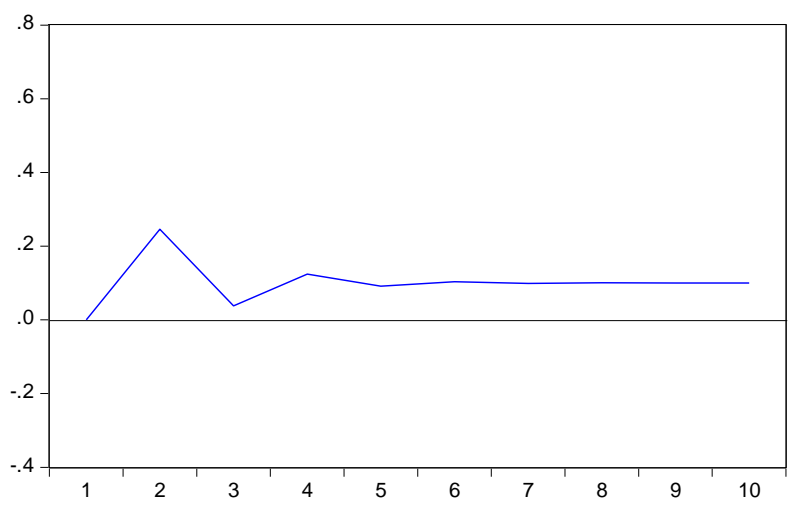

Figure 8. Influences of variable DYEBER on DSHIBOR

Figure 8 shows that DYEBER has a positive correlation with DSHIBOR and has a strong response to a standard deviation of its own. DSHIBOR rises by about 0.3 and in the second phase has a negative effect and in the third phase gradually picks up. After the fourth period, it gradually stabilizes, the effect of which is weakened but is persistent. It is shown that the yield changes of Yu'E Bao have an impact effect on SHIBOR, and this effect persists, which indirectly proves the hypothesis.

Response of DSHIBOR to DTRDTS

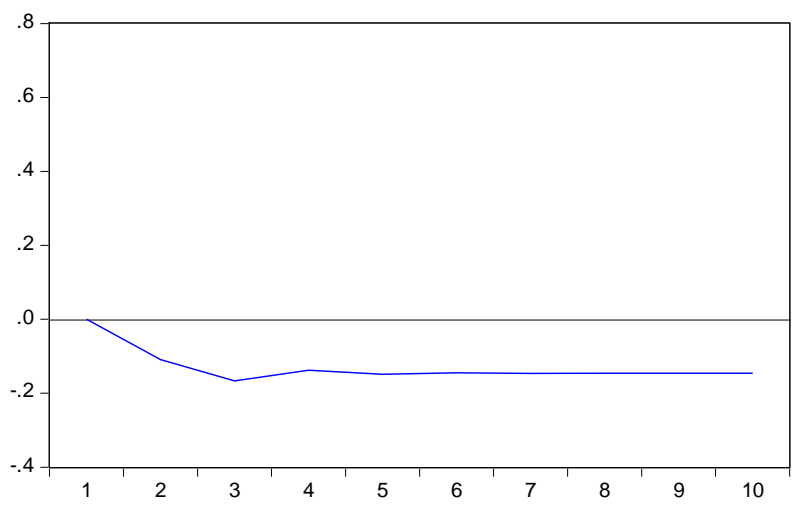

Figure 9. Influences of the variable DTRDTS on DSHIBOR

Figure 9 shows that DTRDTS is negatively correlated with DSHIBOR. Because of the existence of the disturbance term, the variable has a decreasing tendency in the first three periods, but the influence is weak and persistent. The final response value tends to stationary negative. It is indicated that this variable can not fully explain the changes in third-party mobile payment transactions has an impact effect on SHIBOR while the persistent effect can not be negated.

\section{Empirical Conclusions}

In this chapter, the VEC model is established to analyze the interest rate marketization. First, ADF stationary test and co-integration test are carried out and the model is established with the modified first-order difference sequence, suitable VEC model is selected through the determination of the optimal lagged term. The impact of impulse function on the SHOBOR variable is carried out to test the impact of Yu' E Bao's yield and the third-party mobile payment transaction on SHOBOR, which proves the hypothesis.

From reason analysis of the impact results of impulse function, there may be mainly two reasons: First, Yu' E Bao through contracted deposits invests a large amount of money into the money market to get the proceeds. The forepart yield of Yu' E Bao is directly related to contracted deposit interest rate, thus affecting the market interest rate; Second, the introduction of $\mathrm{Yu}$ ' $\mathrm{E}$ Bao attracts extensive attention from investors, with greater market influence. Its high rate of return is expected to have a leading role for participating investors, forcing banks and other financial institutions have to improve the yield of their agent financial products, which is equivalent to increase the cost of bank investment, indirectly affecting the market interest rates. 
From the empirical analysis of this chapter, we can also know that Yu' E Bao alone, such a financial product occupying nearly half of the market share, has a certain impact on the market interest rates, the risk transmission of which can not be overlooked. It plays a certain role in promoting interest rate marketization, and thus has a certain positive effect on the deepening effect of Internet finance.

\section{Suggestions}

1). Financial institutions should establish large department and large business lines of the emerging business architecture system based on the characteristics of financial marketizaion and technicalization and can achieve the process reengineering of emerging business through centralized operations management and whole business process control by headquarters; pay attention to the development of business off balance sheet to achieve steady development of wheels-driven large banks; establish new-matrix emerging business organization structure with business lines as mainline and customer classification as subline.

2). According to the characteristics of the Internet financial management, financial institutions can design more low-threshold financial products and use large data, cloud computing and other technical means for the design. They reduce the purchase threshold while improving the liquidity of financial products, making regular financial products more attractive.

3). The relevant departments should strengthen supervision and risk monitoring, prohibit excessive Internet publication, improve investors' risk awareness and try to prevent potential risks.

\section{Acknowledgments}

While remaining responsible for any errors in this paper, the authors would like to thank guidance and advice of Dr. Wen Shi on preparing the article. We are also particularly grateful to "College students innovation and Entrepreneurship Project" program of Jinan University. Thanks Zhen Du for his personal assistance in manuscript preparation.

\section{References}

Chao-yue, Z. (2015). Research on Reformation of Interest Rates Liberalization and risk management of commercial bank. Technological Development of Enterprise, 34(12).

Guo-qiang, D., \& Peng-fei, F. (2014). Interest Rates Liberalization and The Internet Finance. Modern Economic Research (2014). https://doi.org/10.13891/j.cnki.mer.2014.07.013

Guo-qiang, D., \& Peng-fei, F. (2014). The Liberalization of Interest Rate and the Risks of Bank_—A Study from the Perspective of Shadow Banking and Internet Finance. Finance Forum. https://doi.org/10.16529/j.cnki.11-4613/f.2014.08.009

Ji-fa, W., Ze-dong, X., Yin-tao, B., \& Hao-feng, L. (2014). Influence and countermeasures of internet finance on traditional finance industry. Journal of Shenyang University of Technology (Social Science Edition), 7(4).

Liguo, W. (2016). Interest rate risk management under the condition of market interest rate. Manager' Journal, $27,41$.

Qiang, H. (2014). Pay Attention to Preventing Financial Risks and Promote the Healthy Development of Internet Finance. Price: Theory \& Practice, (3). Retrieved from http://epub.cnki.net/kns/brief/default_result.aspx

Ronald, I. M. (1973). Money and Capital in Economic Development. ISBN: 9787208025912

Ronald, I. M. (1993). The Order of Economic Liberalization - Financial Control in Transition to Market Economy. ISBN: 9780801847431

Shanwen, G. (2014). Marketization of Interest Rate and the Rise of Balance. International Finance, (4). https://doi.org/10.16474/jki.cn.1673-8489.2014.04.005

Xudong, H. (2015). Discussion on the management innovation of commercial banks under the background of market interest rate. Modern Economic Information, 4, 276.

Yong, L., \& Run-Sheng, N. (2016). Analysis and Empirical Research on Internet Finance and Interest Rate Marketing. Journal of Shanghai Finance University, Series No. 133. https://doi.org/10.13230/j.cnki.jrsh.2016.01.008

Yu, Z., \& Jiannan, Z. (2015). Can the Balance of Treasury Influence the Inter - bank Market Interest Rate? - An Empirical Analysis Based on Shibor Data. China Journal of Commerce. (15), 86-88. Retrieved from http://epub.cnki.net/kns/brief/default_result.aspx

Yunyan, Z., \& Yumei, X. (2014). Family financial management strategy based on market interest rate. Friends of 
Accounting, 9, 22-26.

\section{Copyrights}

Copyright for this article is retained by the author(s), with first publication rights granted to the journal.

This is an open-access article distributed under the terms and conditions of the Creative Commons Attribution license (http://creativecommons.org/licenses/by/4.0/). 